\title{
Anton Yasnitsky and René van der Veer (eds.): Revisionist revolution in Vygotsky studies
}

\section{Routledge, London, 2017, 316 pp, \$40.95 (paperback), ISBN-10: 1138929697, ISBN-13: 978-1138929692}

\section{Andrey Maidansky ${ }^{1,2}$ (D)}

Published online: 23 March 2020

(c) Springer Nature B.V. 2020

\begin{abstract}
The authors of the volume under review proclaimed a "revisionist revolution" in Vygotsky studies. With the exception of the two chapters by Ekaterina Zavershneva, everything else in the book is written by Anton Yasnitsky-solo or in collaboration with René van der Veer, Eli Lamdan and Jennifer Fraser. It is demonstrated how the "Vygotsky cult" took shape and eventually spread throughout the world, and how the "myths" and "dogmas" of that cult are later subjected to deconstruction. The editors, van der Veer and Yasnitsky, give an overview of Vygotsky's published works and critically analyze editorial interventions in his texts, mainly in the six-volume Collected Works. The final chapter (Yasnitsky) is devoted to the "birth of the cultural-historical Gestalt psychology," focusing attention on the story of Vygotsky's personal contacts with Gestalt psychologists.
\end{abstract}

Keywords Vygotsky $\cdot$ Luria $\cdot$ Leontiev $\cdot$ Revisionist revolution $\cdot$ Cultural-historical psychology $\cdot$ Gestalt psychology

In 2006, the preparation for the publication of Lev Vygotsky's Complete Works started. In the family archive, there were found many notes on scraps of paper, notebooks, scientific diaries and letters, outlines and segments of books, drafts of articles and transcripts of lectures. All these materials were stored chaotically and have not been studied before. Optimists hurried to announce the 'archival revolution' that had been accomplished. However, for some personal reasons, the work soon stalled. It was not until 2015 that the first volume of the Complete Works came

Andrey Maidansky

meotian@rambler.ru

1 Belgorod National Research University, Belgorod, Russia

2 Institute of Philosophy at the Russian Academy of Sciences, Moscow, Russia 
out-Dramaturgiya i teatr [Dramaturgy and Theater] (edited by V.S. Sobkin, Moscow: Lev Publishers). The second volume has not appeared yet. There is no information about whether any kind of research activity is currently performed in Vygotsky's archive.

Meanwhile, Anton Yasnitsky, an unaffiliated researcher from Toronto, proclaimed a next, "revisionist revolution." In the volume under review, with the exception of the two chapters by Ekaterina Zavershneva, everything else is written by Yasnitsky—-solo or in collaboration with René van der Veer, Eli Lamdan and Jennifer Fraser.

The first part of the volume, "Contexts and People," includes three chapters that sketch the "Stalinist archetype" of Soviet psychological science. The characteristic features of this archetype are centralization and control, patronage and hierarchical structure, cliquism and cultism, composing hagiographies, etc.

Under these conditions, the "Vygotsky cult" took shape and eventually spread throughout the world. At the same time, however, the "revisionist movement" in Vygotsky studies was gaining momentum, challenging the myths and dogmas of the Vygotsky school. This movement reached its apogee-properly speaking, the "revisionist revolution"-in the works of Yasnitsky and his co-authors.

All this creates a fairly new, not so familiar image of Vygotsky and his scientific legacy. Readers-particularly those readers who have always considered themselves as experts in 'Vygotskian psychology'-might feel uneasy and startled by the terra incognita and the new pathways that it suggests. If so, we would consider our mission accomplished. In fact, this is what the 'revisionist revolution' in Vygotsky studies is all about. (p. 93)

The "dogma of the troika" (the alliance of the three: Lev Vygotsky, Alexander Luria \& Aleksei Leontiev) was the first to fall victim of revising the "Vygotsky cult." Yasnitsky's pen decisively cut off Leontiev and the "theory of activity" he created. The book deals exclusively with the "Vygotsky_Luria circle." Leontiev is assigned a peripheral role in a broad "informal personal network of scholars," adjacent to that circle from different sides and in varying degrees (p. 27). Yasnitsky draws five diagrams that demonstrate the placement of figures in this network at different stages of the development of the Vygotsky/Luria theory, up to the beginning of World War II.

Meanwhile, it is known from Luria's autobiography that they were the first to use the label of troika. Vygotsky felt deeply the disagreement on the part of Leontiev; he strove hard to "fertilize comrade Leontiev with the light of the problem of consciousness." Just a month before his death, Vygotsky wrote to Leontiev: "For the time being, I would like to move in the direction that we agreed with you, firmly following the line to the complete closure of our researches" (Vygotsky 2004 , p. 40). Obviously, they managed to chart a path of consensus.

Next, the authors set out to "deconstruct Vygotsky's victimization narrative." The myth of the "Vygotsky ban" was voiced first by Jerome Bruner in his Preface to the translation of Thought and Language (1962). At the Congress in Montreal in 1954, Bruner learned from Soviet psychologists (the delegation included Vygotsky's 
students Aleksei Leontiev and Aleksander Zaporozhets) that Vygotsky's ideas were widely circulated in "informal personal networks," while being officially banned. Ivan Pavlov was praised in public, but within the inner circle they admired Vygotsky. Bruner called this feature of the Soviet academic discourse a "doublespeak," by analogy with the Orwell's "doublethink."

Fraser and Yasnitsky surmise that the story of the ban was composed and spread by Luria, Vygotsky's daughter Gita, "and the like." This fiction laid the foundation for Vygotsky's "somewhat dissident image" as the "victim of an oppressive regime" (pp. 54-55). Subsequently, this image was enshrined in the biographies of Vygotsky in Russia and around the world.

To deconstruct it, the authors offer an alternative explanation for the historical fact that Vygotsky's works were not published for twenty years, from 1936 to 1956. As Fraser and Yasnitsky contend, the reason for that was not a mythical ban, but a reluctance of Vygotsky's direct students to publish his writings. This conjecture is supported with evidence from Georgy Shchedrovitsky and Vladimir Zinchenko.

However, citing lengthy fragments from Shchedrovitsky's interview of 1980, Fraser and Yasnitsky omit other stories about the battles Shchedrovitsky led against the higher-ups who tried "zakryt' Vygotskogo"- "to close Vygotsky down" (Shchedrovitsky 1980), and how the party leadership of the Institute of Psychology of the Soviet Academy of Sciences fought to prevent the publication of Vygotsky's Selected Works in 1956. This seems a very eloquent confirmation of the "victimization narrative"-yet at the beginning of the "Thaw."

It was not a complete, total ban, as in cases of 'enemies of the people.' Indeed, there existed significant references to Vygotsky in the scientific and educational literature of the Stalin era, not to mention the entry "Vygotsky," written by Luria and Leontiev for the Big Soviet Encyclopaedia (1940). But the fact remains: within two years immediately after Vygotsky's death, six of his books were published, plus a dozen smaller works, and nothing over the next 20 years.

This fact alone easily outweighs all the 'deconstructing' argumentations. It seems weird to explain it by the students' reluctance, as Fraser and Yasnitsky do. Are we to believe that for two years after the death of their teacher, the desire was bubbling over, and then suddenly disappeared in each and every one? And why did Vygotsky's widow, who kept the archive all this time, attend to publishing his works only twenty years later? The "revolutionaries" would do well to reflect on these simple questions.

In the fourth chapter, van der Veer and Yasnitsky give an overview of Vygotsky's published works and critically analyze editorial interventions in his texts, mainly in the six-volume Collected Works. They claim that the editors of the Works did with the manuscripts whatever they pleased, without bothering themselves with a justification, or at least a description of their manipulation of the texts: "We are left with the uneasy feeling that we have been robbed of the historic Vygotsky..." (p. 74). This is true: Van der Veer and Yasnitsky have made serious efforts to separate the wheat from the chaff, and here lies their most important contribution to Vygotsky studies.

It is worth noting that, even before the publication of the Collected Works (1982-1984), there had been talks about "falsification" of the Vygotsky's 
manuscripts. For example, in reference to the Collected Works, Shchedrovitsky wrote: "Vygotsky was dismembered there and rewritten under the theory of activity" (Shchedrovitsky 1980). It is hard to tell how justified such an accusation might have been, but it is clear that the editors dealt with the manuscripts badly, rearranging the original materials for their own purposes and ideological reasons. Now, a painstaking restoration of those texts is needed in order to recover the authentic Vygotsky.

Van der Veer and Yasnitsky describe the situation in the darkest colours. They speak of "so profoundly and shamelessly edited (and distorted) Soviet publications of 1950-1980" (pp. 92-93). Examples of the "fairly amazing episodes of actual falsification of Vygotsky's original texts" are the merging of two manuscripts into one under the title The History of the Development of Higher Mental Functions and the reverse translation of Tool and Sign in the Development of the Child (the text was translated back from the English without mentioning loss of the Russian original, written presumably around 1930). Some of Vygotsky's books, published shortly after his death, were compiled by students from his lecture notes or composed of manuscripts of different years, as in the case of Thinking and Speech (1934).

Making a list of his authentic and the most foundational publications, the authors divide Vygotsky's work into an "instrumental" period and a "holistic" one. The period before 1930 is qualified as a period of "mechanistic and fairly reductionist thinking." And in the 1930s, they say, his views underwent a "major shift" under the influence of contacts with Gestalt psychologists (p. 92).

The rejection of Vygotsky's understanding of personality, with all its higher psychological functions, as "the social in us," the denial of continuity between the two periods of his work, the pejorative labels "mechanistic" and "reductionist" - that is, indeed, "a fairly new, not so familiar image of Vygotsky" in 1920s, drawn by van der Veer and Yasnitsky (p. 93).

Perhaps this explains the burning desire of the book authors to separate Leontiev from the "Vygotsky/Luria circle." In those years when cultural psychology was born, Leontiev worked hand in hand with Luria in the team of the "instrumental" Vygotsky. But then Leontiev entered into a "confrontation" (using his own expression) with the "holistic" Vygotsky, reaching "the apogee of the divergence" at the end of 1932 (Leontiev 2005, p. 376). He blamed Vygotsky for a "turn to Spinoza" and for shifting the research focus to the problem of affects.

Van der Veer and Yasnitsky eliminate The Teaching about Emotions from the list of Vygotsky's "fundamental works," that "give us an idea about how and in what direction Vygotsky's thought developed during the last years of his life" (p. 93).

In that unfinished work, Vygotsky declares Spinoza's teaching on rational mastering of affects (emotions, passions) "a turning point of the whole history of psychology and its future development” (Vygotsky 1999, p. 105), and maintains that "not just the method, but also the content of Spinoza's teaching on passions is advanced as a guiding source for developing investigations in a new direction, in the direction of understanding man" (Vygotsky 1999, p. 220).

These lines were written by the already deeply "holistic" Vygotsky, and that was a "turning point" of his own psychological research, first and foremost. But this "new direction of understanding man" turned out to be alien to and incomprehensible for the authors of the reviewed monograph. Obviously, Spinozism did not fit 
into the construction of "cultural-historical Gestalt psychology," which Yasnitsky announces to be the last word of Vygotsky (Ch. 9). This makes clear why Vygotsky's cherished manuscript The Teaching about Emotions, devoted to "the blessed memory of [his] father," is slurred over by Yasnitsky and his co-authors.

Spinoza's name is found only in the two chapters by Zavershneva (Chs. 5 and 6), which somehow stand apart in the book. These chapters are the abbreviated English translations of her articles from 2007 to 2008 which initiated the "archival revolution" in Vygotsky studies. The problem was that the original articles largely sustained the "Vygotsky cult." So they had to be purified by revisionist fire from blameworthy mythologems.

In both articles, Zavershneva supported the "victimization narrative." The editors of the volume have struck out all these references. In place of the words about the "ban on publications," a reference to Ch. 3 is inserted, in which Fraser and Yasnitsky argue the opposite (p. 276).

Zavershneva never speaks about the split of Vygotsky's legacy into "mechanistic" and "holistic" layers. On the contrary, she emphasizes that "there is a deep tie, continuity, and not a rupture between his old and new views" (Zavershneva 2008, p. 133). She rightly sees this tie in the idea of freedom, which forms the "constant background of Vygotsky's thought" (Zavershneva 2007, p. 73). I would add that Vygotsky defines freedom in a Spinozist way, as "the affect in the concept"-but in no wise as some arbitrary choice or undetermined activity.

Needless to say that these passages did not pass censorship on the part of the volume's editors. A "revisionist" phrase about the "contrast" between Vygotsky's works of the two periods has appeared instead (p. 132).

The high appreciation of Luria's expedition to Uzbekistan (1931-1932) was deleted from the translated text. Lamdan and Yasnitsky believe that the expedition failed and became an experimental refutation of the cultural-historical theory of perception (the theme of Ch. 8).

The mention of Vygotsky's supposed co-authors Leontiev and Luria (here is the troika again!), whose initials were marked out by his own hand in the outline of his book Thinking and Speech, was deleted, as well as many other facts and judgments that are inconvenient for the creators of the "revisionist revolution". Furthermore, Zavershneva's phrase "Lewin was one of Vygotsky's most serious opponents" in the English-language revision was turned inside out becoming the following statement: "Lewin was among the most outstanding intellectuals influencing Vygotsky" (p. 137).

In the light of this sort of "deconstruction," the imperative statement, formulated by van der Veer and Yasnitsky as a "second commandment for the translator," looks a bit comical: "Honor thy author. Under no circumstance can you manipulate the original. The author's word and thought [are] sacred" (p. 173). Still, the 'revisionist revolutionaries' can make exception for a colleague, so long as supreme interests of revolution require that.

As for the Zavershneva's archival survey, it was almost unaffected by the revision, but it is advisable to consult the more recent edition of the same materials and comments: Vygotsky's Notebooks. A Selection (Zavershneva and van der Veer 2018). 
In the short but useful Ch. 7, van der Veer and Yasnitsky conduct an examination of the existing English-language translations of Vygotsky, with reference to their history and with an analysis of various types of omissions and errors.

Ch. 8 (by Lamdan and Yasnitsky) is titled: "Did Uzbeks have illusions? The Luria-Koffka controversy of 1932." In this controversy, the authors assign an unconditional victory to Kurt Koffka, a defender of the invariance of the laws of perception, as opposed to Vygotsky and Luria, who hoped to discover cultural-historical differences between "primitives" and educated Europeans in perception processes.

The final Ch. 9 (by Yasnitsky) is devoted to the "birth of the cultural-historical Gestalt psychology of Alexander Luria, Kurt Lewin, Lev Vygotsky, and others" (p. 201). The attention is focused on the story of Vygotsky's personal contacts with Gestalt psychologists, especially with Lewin and his students (such as Gita Birenbaum and Bluma Zeigarnik who moved to Moscow and worked closely with Vygotsky).

The theoretical core of the newly-minted hybrid-“cultural-historical Gestalt psychology"-seems obscure. It is described only in the most general terms: "holism," "Galilean mode of thinking" (p. 217) plus a couple of words in other chapters. Yasnitsky did not suggest a solid reinforcement of his hypothesis by analyzing Vygotsky's texts. As for Vygotsky's criticism of the Gestaltists, Yasnitsky characteristically does not notice it. But to be fair, he did not promise that much. Yasnitsky saw his revolutionary mission in drawing a new, unfamiliar image of Vygotsky and startling the old Vygotskian guard.

The revolution, as Alexander Herzen said, should be not only a "sword that slashes," but also a "force that stores." The authors, with the exception of Zavershneva, slash more than they store. Deconstruction prevails over constructing. Most chapters are lacking objective, unbiased and balanced judgments. Nevertheless, the monograph is an interesting read, and it provides high-calorie food for the mind. I would recommend it to those who want to understand Vygotsky more deeply and are able to think critically. But it is definitely not an apt reading for beginners in Vygotsky studies.

\section{Compliance with ethical standards}

Conflict of interest The author declares that he has no conflict of interest.

\section{References}

Leontiev, A. N. (2005). Ustnaya avtobiografiya A. N. Leontieva [A. N. Leontiev's oral autobiography]. In A. A. Leontiev, D. A. Leontiev, \& E. E. Sokolova (Eds.), Aleksei Nikolaevich Leontiev. Deyatel'nost', soznanie, lichnost' (pp. 367-385). Moscow: Smysl.

Shchedrovitsky, G. P. (1980). "Ya vsegda byl idealistom" ["I have always been an idealist"]. Retrieved January 27, 2020 from http://textarchive.ru/c-2504799-p5.html. 
Vygotsky, L. S. (1999). The teaching about emotions. In R. W. Rieber \& A. S. Carton (Eds.), The collected works (Vol. 6, pp. 69-235). New York: Kluwer Academic/Plenum Publishers.

Vygotsky, L. S. (2004). Pis'ma k uchenikam i soratnikam [Letters to students and colleagues]. Vestnik Moskovskogo Universiteta: Psikhologija, 3, 3-40.

Zavershneva, E. (2007). "Put' k svobode" (K publikatsii materialov iz semeinogo arkhiva L. S. Vygotskogo) ['The path to freedom' (On the publication of the materials from the family archive of L. S. Vygotsky)]. Novoe Literaturnoe Obozrenie, 85(3), 67-90.

Zavershneva, E. (2008). Zapisnye knizhki, zametki, nauchnye dnevniki L. S. Vygotskogo: Rezultaty issledovaniya semeinogo arkhiva [Notebooks, notes, scientific diaries of L. S. Vygotsky: The results of the investigation of the family archive, Part 2]. Voprosy Psikhologii, 2, 120-136.

Zavershneva, E., \& van der Veer, R. (Eds.). (2018). Vygotsky's notebooks. A selection. Singapore: Springer.

Publisher's Note Springer Nature remains neutral with regard to jurisdictional claims in published maps and institutional affiliations. 